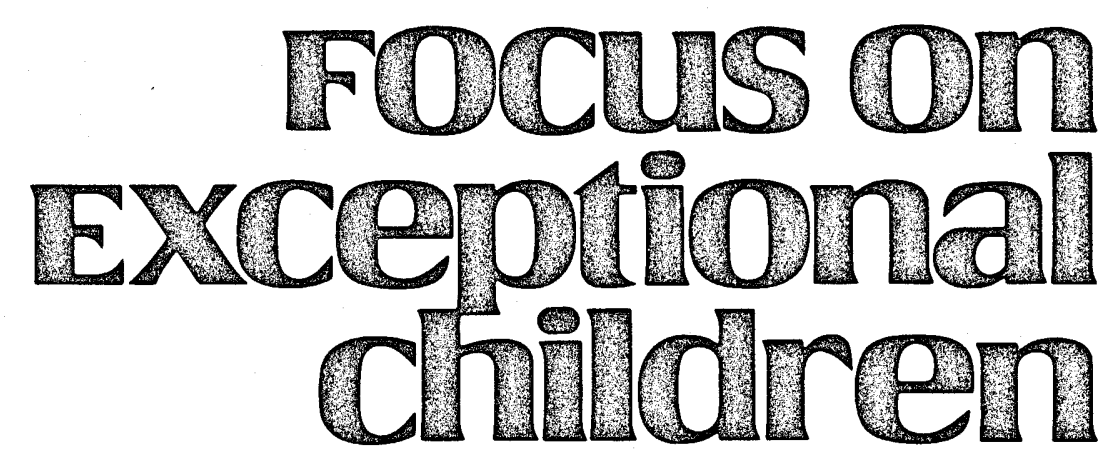

\title{
Structuring Classrooms Through Levels Systems
}

\section{Anne M. Bauer and Thomas M. Shea}

The implementation of levels systems has recently increased in public school programs for students with behavioral disorders. These systems, emerging from residential and treatment programs for students with complex behavioral disorders, have been applied with adolescents involved in substance abuse (Coghlan, Gold, Dohrenwend, \& Zimmerman, 1973), adolescents who are incarcerated (Reid, 1979), and students in residential treatment facilities (Mitchell, 1980; Rosenstock \& Levy, 1978; Gable \& Strain, 1981). Though levels systems are gaining popularity, there are few reports in the literature of their application in public school settings (Braaten, 1979; Gersten, 1984; LaNunziata, Hunt, \& Cooper, 1984; Bauer, Shea, \& Keppler, 1986; Mastropieri, Jenne, \& Scruggs, 1988). The reports that do exist suggest that levels systems facilitate student self-reinforcement and self-management, the durability and generalization of treatment gains, and the fading of other management structures such as a token economy.

This article defines levels systems and presents a brief overview of the characteristics of levels systems. A review of the literature points out that levels systems address variables related to effective instruction and behavior management. Three systems are presented here, followed by step-by-step procedures for developing a levels system. The article concludes with a discussion of advantages and disadvantages of the levels system approach to classroom management.

Anne Bauer is an Assistant Professor, Department of Early Childhood, Special Education, Health, Physical Education, and Nutrition, University of Cincinnati. Thomas Shea is a Professor, Department of Special Education, Southern Illinois University at Edwardsville. 


\section{DEFINITION OF LEVELS SYSTEMS}

Levels systems are classroom structures, or "regularized patterns for conducting work and processing information in classroom environments" (Doyle \& Carter, 1984, p. 127). Levels systems provide an organizational framework through which a range of behavior management strategies are applied to shape students' social, communicative, and academic behaviors to preestablished levels. As students progress through behavioral, social, and academic levels, expectation and privileges are increased. Representative strategies that may be applied within this organizational framework include token economy, positive reinforcement, contingency contracting, social skills training, group and individual counseling, and expressive arts therapy (Bauer et al., 1986).

Though each levels system must be designed to respond to the unique characteristics of the individuals and the instructional setting in which it is to be applied, the systems

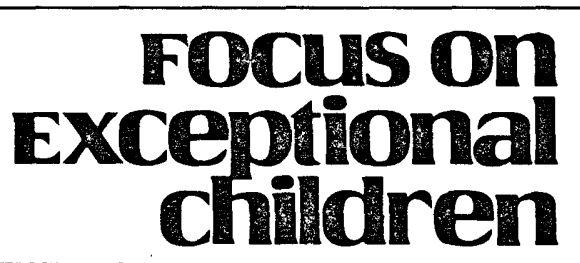

FOCUS ON EXCEPTIONAL CHILDREN (ISSN0015-51IX) (USPS 203-360) is published monthly except June, July, and August as a service to teachers, special educators, curriculum specialists, administrators, and those concerned with the special education of exceptional children. This publication is annotated and indexed by the ERIC Clearinghouse on Handicapped and Gifted Children for publication in the monthly Current Index to Journals in Education (CIJE) and the quarterly index, Exceptional Child Education Resources (ECER). It is also available in microform from Xerox University Microfilm, Ann Arbor, MI. Subscription rates: Individuals, $\$ 24$ per year; institutions, $\$ 30$ per year. Copyright (C) 1988 , Love Publishing Company. All rights reserved. Reproduction in whole or part without written permission is prohibited. Printed in the United States of America. Second class postage is paid at Denver, Colorado.

POSTMASTER: Send address changes to:

Love Publishing Company

Executive and Editorial Office

1777 South Bellaire Street

Denver, Colorado 80222

Telephone (303) 757-2579

EDITORIAL BOARD

$\begin{array}{cc}\begin{array}{c}\text { Edward L. Meyen } \\ \text { University of Kansas }\end{array} & \begin{array}{c}\text { Glenn A. Vergason } \\ \text { Richard J. Whelan }\end{array} \\ \text { University of Kansas Medical Center } \\ \begin{array}{cc}\text { Stanley F. Love } \\ \text { Publisher }\end{array} & \text { Carolyn Acheson } \\ & \text { Senior Editor }\end{array}$

have several characteristics in common. Each system includes a description of four to six levels of behavioral, academic, and social expectations and the criteria for movement from one level to another. The description of each level includes an explicit explanation of behaviors, expectations, restrictions, and privileges. Within this framework there is the opportunity for extensive variation and individualization.

\section{SUPPORT FROM THE LITERATURE FOR LEVELS SYSTEMS}

Levels systems are reponsive to two issues that are discussed frequently in the current literature on effective classroom interaction: explicitness and problem ownership.

\section{Explicitness}

The literature clearly indicates a need for explicitness on behalf of teachers in their interactions with students. Brophy (1982) states that "teacher failure to explain the purpose of activities adequately often produces discrepancies between the meaning of those activities as seen by teacher and students" (p. 10). Levels systems are responsive to this need to explicitly describe the purpose of activities.

\section{STATEMENT OF OWNERSHIP, MANAGEMENT AND} CIRCULATION

Date of Filing: September 30, 1988

Title of Publication: FOCUS ON EXCEPTIONAL CHILDREN

Frequency of Issue: Monthly except June, July, and August

Location of Known Office of Publication: 1777 S. Bellaire St., Denver, CO 80222

Location of Headquarters of Publisher: 1777 S. Bellaire St., Denver, CO 80222

Name and Address of Publisher, Editor, and Managing Editor: Stanley F. Love,

1777 S. Bellaire St., Denver, CO 80222

Owner: Stanley F. Love

Extent and Nature of Circulation:

$\begin{array}{lcr} & \begin{array}{c}\text { Average No. Copies } \\ \text { Each Issue During } \\ \text { Preceding 12 Months }\end{array} & \begin{array}{c}\text { Single Issue } \\ \text { Nearest to } \\ \text { Filing Date }\end{array} \\ \text { Total No. Copies Printed } & 3,013 & 2,900 \\ \text { Paid Circulation } & 0 & 0 \\ \quad \text { Sales through Dealers, etc. } & 2,331 & 2,313 \\ \quad \text { Mail Subscriptions } & 2,331 & 2,313 \\ \text { Total Paid Circulation } & 250 & 278 \\ \text { Free Distribution } & 2,581 & 2,591 \\ \text { Total Distribution } & 432 & 309 \\ \text { Office Use and Left Over } & 3,013 & 2,900 \\ \text { Total } & & \end{array}$

I certify that the statements made by me above are correct and complete.

(Signed) Stanley F. Love, Publisher 
For example, in an interview with one of the authors, a student who had been placed in a classroom with a levels system was able to describe the purpose of group meetings, the behavior required for participation and to earn rewards, and the level of behavior required to leave the classroom and enter a less restrictive setting. The behaviors the student described were equivalent to those the teacher described. The system, then, has the potential to decrease the discrepancies between teacher and student perceptions of the meaning of classroom activities and goals.

Hood, McDermott, and Cole (1980) provide additional support for the explicit nature of levels systems. They suggest that teachers should describe the social organization of situations in which individuals display abilities and disabilities. Teachers should define task environments in terms of the supports students need to organize their behavior and their environment. The specific levels within a system provide students with expectancies and privileges that facilitate the displays of abilities, rather than allowing them to enter situations in which their disabilities are evident. Levels carefully define task environments and provide greater structure and less student choice and initiative at lower levels, with gradually increasing responsibilities in these areas at higher levels.

Levels systems encourage the development of a classroom learning orientation. Marshall (1987) suggests that to build a classroom learning orientation, (a) activities should be framed to provide initial motivation; (b) reinforcement and teacher attention should be focused on redirection and support; (c) errors should be addressed as ways to gain insight into learning; (d) responsibility for learning and evaluation should be shared; (e) expectations and standards should be explicitly stated; and (f) management strategies should be proactive, helping students toward self-regulated learning, rather than simply work or compliance. Levels systems provide initial and ongoing motivation through increased privileges with attention on meeting goals. Achievement and maintenance of a specific behavioral level is shared by teacher and student, with explicitly stated goals at each level. Finally, the structure of levels systems provides a gradual increase in self-regulated learning.

From a sociolinguistic perspective, levels systems are also appropriate. Puro and Bloome (1987) suggest that what students traditionally learn in classrooms is how to contextualize what is happening in the room, their personal behavior, others' behavior, academic tasks, and communicative contexts. Thus, the communicative context of the classroom becomes a frame through which students interpret and redefine classroom learning. As a consequence of the usual invisibility of this frame, problems arise among both teachers and students. In levels systems, however, the behavioral and communicative context is visible, with explicit indications of responsibilities, privileges, and the means of increasing both responsibilities and privileges.

The explicit nature of levels systems fosters self-direction (Scobie, 1983). The frequency of ambiguous situations, which decrease successful interaction, is decreased. The explicit nature of the responsibilities and privileges within the classroom context becomes mutually reinforcing.

\section{Problem Ownership}

Paris and Oka (1986) suggest that self-management may be fostered by encouraging students to have individual standards for success and failure, so that failure is defined relative to one's personal expectations and experiences instead of by comparisons to other students. Levels systems are responsive to this suggestion, in that each student works individually to accomplish personal goals. Problem ownership, then, is the student's rather than the teacher's.

Fantuzzo, Polite, Cook, and Quinn (1988) contrasted the effectiveness of teacher and student management of classroom interventions. In their review of elementary-age students, which did not include students who were mentally retarded, student-management interventions resulted in greater treatment effects than teacher-management interventions. A significant positive relationship, in fact, was found between the number of intervention components that were student-management and treatment effects.

The literature on problem ownership also describes a continuum of support in which the teacher begins in a directive manner, moving to contracting, then to delegating, and finally to collaborating with students. This gradual fading of teacher support is reflective of increases in self-regulating behavior (Scobie, 1983). As students progress through a levels system, the teacher's role becomes less directive and more supportive.

\section{LEVELS SYSTEMS IN THE LITERATURE}

Coghlan et al. (1973) authored one of the earlier reports of the use of a levels system. A four-level system, associated with a token economy, was used in an adolescent substance abuse program. The levels system was believed to increase participants' tolerance for delayed gratification and increase the use of self-reinforcement.

In another study with adolescents, Mitchell and Cockrum (1980) described a levels system implemented in a treatment 
facility. In this system, weekly staff meetings were held to determine assignment to levels. Each level progressively increased student privileges and allowance money. In comparison to the application of positive peer culture, they reported more behavioral incidents and more aggression in the levels system. Rosenstock and Levy (1978) reported on a system, used in a psychiatric hospital, which allowed the staff to promote a patient to another level for therapeutic purposes, rather than to promote patients on the basis of accumulated points. They suggested that use of the levels system increased identification with successful peer models and greater parent support.

Classroom-based levels systems also are reported in the literature. Braaten (1979) and LaNunziata, Hunt, and Cooper (1984) implemented levels systems to assist in the successful fading of token economies. Gersten (1984) described a five-level system employed in classrooms for adolescents. Bauer, Shea, and Keppler (1986) reported on levels systems used in public school programs at both the elementary and secondary levels. Shea and Bauer (1987) and Walker and Shea (1988) described levels systems implemented in a secondary school special education program for students with behavioral disorders.

Mastropieri, Jenne, and Scruggs (1988) reported the results of two studies on the efficacy of a levels system in a high school English class resource room serving students with behavioral disorders and those with learning disabilities and behavior problems. Their data indicate that a four-level system was effective in decreasing disruptive and off-task behavior, and that a three-level system was effective in increasing task completion. Students engaged in contracting, self-monitoring, and peer evaluation, and they worked solely for greater independence and responsibility as reinforcers.

\section{SAMPLE LEVELS SYSTEMS}

To illustrate the implementation of levels systems, three sample programs are described. The first currently is used with elementary students who have severe behavior disorders, the second with secondary students having behavioral disorders, and the third in a public school program for students with moderate behavior disorders.

\section{An Elementary Levels System}

The levels system used in the Greater Clark County Special Education Cooperative (GCCSEC) day treatment program for students with severe behavioral disorders, rep- resented in Table 1, was developed to increase self-management. Progress through the system is monitored by both student and teacher. Points are earned continuously during the school day in the areas of academic, behavior, and social skills. Increased frequency of appropriate behaviors and decreased frequency of inappropriate behaviors are both measured to determine progress. The goals and objectives of the GCCSEC levels system are individually determined, and staff meetings are held weekly to review student performance, revise expectations, and change levels.

The GCCSEC system is composed of five levels: Level 1 (Entry Level), Level 2 , Level 3 (Transition Level, during which students begin reintegration into classes housed in local public schools), Level 4 (Follow-up Level, during which students continue to be monitored by the Day Treatment Program staff), and Ground Level (Disciplinary Level). Reinforcement is faded in this system through increasing the length of time between awarding points. If a student fails to meet requirements to maintain the current level, the student is placed on the previous level for a 1-week period before being moved permanently to the lower level. If, during this 1-week probation period, the student earns $80 \%$ of the possible points, he or she regains the privileges of the original level. Each level's expectations and privileges include those of the previous levels.

\section{A Secondary School Day Treatment Center Levels System}

Children's Center for Behavior Disorders (CCBD), which serves students with severe behavior disorders, employs a five-level system, designed to increase student responsibility and self-control. Points are earned for specific classroom and school behavior, but, unlike the GCCSEC system, points earned that day may be deducted for specific inappropriate behaviors. Individual student contracts, negotiated by student, teacher, therapist, and counselor, are used to individualize each student's goals.

In addition, reflective of recurrent issues with adolescents, criteria pertaining to attendance, participation in group meetings and therapy, and serious offenses (deliberate aggression against staff or student, possession of drugs or alcohol, possession of a weapon, attending school under the influence of drugs or alcohol) are included in the system. Students are provided with a handbook describing the system in great detail. Students are required to formally petition to move from level to level. A sample level from this system is presented in Table 2 . 


\section{A Public School Special Class Levels System}

The Personal Adjustment Levels System (PALS), a fivelevel system for secondary students with moderate behavior disorders, is designed to facilitate self-motivation and academic achievement. Table 3 illustrates PALS. The goal of the system is reintegration into regular education. Smallgroup and individual counseling sessions are an integral part of the treatment program. All students in Levels I through IV are required to attend group. Students who fail to attend group remain at Day 1 of their present level.

Unlike the previous systems, initial level placement is determined by a support team. There is a minimum stay at each level. Students can earn bonus days for appropriate behavior or lose days for suspension and inappropriate behavior.

\section{DESIGNING A LEVELS SYSTEM}

These three examples represent the flexibility of the levels system approach. Each system includes a description of each level, criteria for movement between levels, and the behaviors, expectations, and privileges for each level. Each level system must be developed to reflect the needs of the individual and the group with which it is applied and, in all probability, will require periodic modification. To design an effective levels system, the following steps are suggested:

1. Determine the entry-level behaviors of students for whom you are designing the system. For example, students who enter the GCCSEC program have difficulty initiating assignments independently, interacting appropriately with peers and adults, and attending to task. Initially they are removed from the group if they exhibit inappropriate behavior more than 10 times each day. Entry-level behaviors may be classified in several ways. In the GCCSEC system, they are classified as behavioral, academic, and social.

2. Determine the terminal-level behaviors for the students for whom you are designing the system. For the GCCSEC students, terminal behaviors are those of the next less restrictive setting (e.g., special class for students with behavior disorders in public school). In the CCBD system, terminal behaviors are expectations of the teachers in secondary school regular and special class, and supervisors and employers in a work setting. Behaviors should be expressed in a positive manner (e.g., "keeps hands and feet to self," rather than "no hitting or kicking"; "be on time for work and bring needed materials" rather than "don't be late, and don't forget to bring your materials").
3. Determine the intermediary behaviors between entry and terminal behaviors. In this step, list at least two, but no more than four, sets of behaviors that evenly distribute expectations between those established for the entry and terminal levels. This gradual increase in expectations is represented in the CCBD system, in which Level Two students must complete work on time for four of five assignments, four days a week, and Level Three students must complete four of five assignments, five days a week. Write the sets of graduated expectations on separate sheets of paper labeled "Level 1" through "Level 4." At this point you may wish to consider naming levels, rather than using numeral or letter designations. We have observed systems in which levels have been named for colors, animals, or other categories (e.g., freshman, sophomore, junior, and senior).

4. Consider a disciplinary level. If a disciplinary level is desired, describe its expectations and limits separately. In the GCCSEC system, expectations of the disciplinary level are the same as expectations for the level immediately below the one the student was on prior to the offense resulting in Ground Level placement. In the CCBD program, restrictions unique to the disciplinary level are designated.

5. Consider a transition and follow-up level. A transition level would focus on behaviors in a shared placement in the special program and a less restrictive program. Expectations for this level may include participation in support activities (counseling, therapy), interactions with the new teacher and students, attendance, and completion of assignments. In the follow-up level, these supports are systematically faded.

\section{Determine the privileges appropriate for students be-} ginning the program (entry level) and leaving the program (terminal level). Entry-level privileges usually are limited and are closely supervised. Terminal-level privileges encourage greater student freedom and responsibility and are similar to the privileges available to students in the less restrictive setting.

7. Evenly distribute privileges among the levels. Remember to plan for the fading of student supports and increased personal responsibility for behavior as the student progresses through the system.

8. Develop a mechanism for moving among levels. Several mechanisms for moving among levels have been suggested in the literature. Students may be required to stay at each level for a minimum period of time, such as in the 
TABLE 1

GCCSEC Level System

\begin{tabular}{|c|c|c|c|c|c|}
\hline & Levell & Level II & $\begin{array}{c}\text { Level III } \\
\text { (1/2-day Transition) }\end{array}$ & \begin{tabular}{|c} 
Level IV \\
(Complete Transition) \\
\end{tabular} & Ground Level \\
\hline $\begin{array}{l}\text { Maximum } \\
\text { Length of Stay }\end{array}$ & 9 weeks & 9 weeks & 6-18 weeks & 6 weeks & $1-5$ days \\
\hline $\begin{array}{l}\text { Requirements } \\
\text { for Advancing } \\
\text { to Next Level }\end{array}$ & $\begin{array}{l}90 \% \text { of possible points } \\
\text { ( } 45 \text { of } 55 \text { days); no } \\
\text { more than } 10 \text { time- } \\
\text { outs }\end{array}$ & $\begin{array}{l}90 \% \text { of possible points } \\
\text { ( } 45 \text { of } 55 \text { days); no } \\
\text { more than } 5 \text { time- } \\
\text { outs } \\
\end{array}$ & $\begin{array}{l}\text { Min.: } 90 \% \text { of possible } \\
\text { points ( } 30 \text { of } 35 \text { days); } \\
\text { Max: } 90 \% \text { of possible } \\
\text { points ( } 90 / 100 \text { days) }\end{array}$ & $\begin{array}{l}\text { Meets criteria } \\
\text { established by public } \\
\text { school SEH teachers }\end{array}$ & $\begin{array}{l}\text { Level I-80\% pos. pts. } \\
\text { Level II-85\% pos. pts. } \\
\text { Level II-90\%pos. pts. }\end{array}$ \\
\hline $\begin{array}{l}\text { Academic } \\
\text { Expectations }\end{array}$ & $\begin{array}{l}\text { Starts assignments } \\
\text { on command; during } \\
\text { weeks } 1-5 \text {, on task } \\
\text { for } 15 \text { min. of each } 1 / 2 \\
\text { hour; weeks } 6-9, \text { on } \\
\text { task } 20 / 30 \text { min. of each } \\
1 / 2 \text { hr. (not necessarily } \\
\text { consecutively } \\
\end{array}$ & $\begin{array}{l}\text { Starts and completes } \\
\text { assignments within } \\
\text { specified time; } \\
\text { on-task behavior: } \\
\text { Weeks 1-2-20/30 } \\
\text { min.; weeks 3-4-25/45 } \\
\text { min.; weeks 5-9- } \\
30 / 45 \text { mins. }\end{array}$ & $\begin{array}{l}\text { Starts and completes } \\
\text { assignments within } \\
\text { specified time; stays } \\
\text { on task independently } \\
30 \text { minutes at a time }\end{array}$ & $\begin{array}{l}\text { Meets criteria } \\
\text { established by public }\end{array}$ & $\begin{array}{l}\text { Same expectations } \\
\text { for level below the one } \\
\text { student was on prior } \\
\text { to offense resulting } \\
\text { in Ground Level } \\
\text { placement }\end{array}$ \\
\hline
\end{tabular}




\begin{tabular}{|c|c|c|c|c|c|}
\hline $\begin{array}{l}\text { Social Skills } \\
\text { Expectations }\end{array}$ & $\begin{array}{l}\text { Demonstrates ability } \\
\text { to participate in } \\
\text { supervised activity } \\
\text { with } 1 \text { student; attends } \\
\text { daily class meetings; } \\
\text { participates in } \\
\text { individual activity } \\
\text { time }\end{array}$ & $\begin{array}{l}\text { Demonstrates ability } \\
\text { to interact } \\
\text { appropriately with } 2 \text { or } \\
\text { more peers at a time } \\
\text { without supervision; } \\
\text { daily contributions to } \\
\text { discussions during } \\
\text { class meetings; } \\
\text { compliments others at } \\
\text { least once a day; } \\
\text { daily participation in } \\
\text { groups (social skills } \\
\text { and vocational } \\
\text { education) }\end{array}$ & $\begin{array}{l}\text { Daily contributions } \\
\text { during class meetings; } \\
\text { daily participation in } \\
\text { social skills and } \\
\text { vocational education } \\
\text { groups; encourages } \\
\text { peers regularly; meets } \\
\text { all criteria established } \\
\text { in SEH program in } \\
\text { regular school }\end{array}$ & $\begin{array}{l}\text { Meets criteria } \\
\text { established in SEH } \\
\text { program in regular } \\
\text { school }\end{array}$ & $\begin{array}{l}\text { Same expectations for } \\
\text { level below the one } \\
\text { student was on prior } \\
\text { to offense resulting in } \\
\text { Ground Level } \\
\text { placement }\end{array}$ \\
\hline Privileges & $\begin{array}{l}\text { Free time using } \\
\text { equipment in } \\
\text { classroom; special } \\
\text { activities with staff } \\
\text { members; Levell } \\
\text { purchases in class } \\
\text { store }\end{array}$ & $\begin{array}{l}\text { Unescorted restroom } \\
\text { and drink breaks; } \\
\text { sets table at lunch; } \\
\text { runs errands within } \\
\text { building; Level II } \\
\text { purchases in class } \\
\text { store, snacks and } \\
\text { soft drinks at } \\
\text { specified times; } \\
\text { locker assignment }\end{array}$ & $\begin{array}{l}\text { Up to } 1 / 2 \text {-day } \\
\text { placement in regular } \\
\text { school program; lunch } \\
\text { outside of school with } \\
\text { staff member once a } \\
\text { week; "free" Friday } \\
\text { once a month; } \\
\text { unsupervised to and } \\
\text { and from bus } \\
\text { Early transition with } \\
30 \text { consecutive days } \\
\text { of }+90 \%\end{array}$ & $\begin{array}{l}\text { Includes all privileges } \\
\text { used in SEH program } \\
\text { in regular school }\end{array}$ & $\begin{array}{l}\text { One-half the amount } \\
\text { of free time earned by } \\
\text { student prior to } \\
\text { offense resulting in } \\
\text { Ground Level; } \\
\text { restricted choice of } \\
\text { activities for free time } \\
\text { (no computer, record } \\
\text { player, tape recorder, } \\
\text { overhead projector); } \\
\text { scheduled restroom } \\
\text { and drink breaks } \\
\text { supervised at all times }\end{array}$ \\
\hline
\end{tabular}

\section{Offenses resulting in ground level placement:}

Physical abuse to peer (3 days)

Physical abuse to staff ( 5 days)

Running away from assigned area

Destruction of property

Possession of drugs

Setting off fire alarm

Possession of weapons

Excessive swearing (student must be given warning before being placed on Ground Level for swearing) 


\section{TABLE 2}

\section{Level Two from CCBD Levels System}

Level Two is for the person who is trying to change but is still having great difficulty getting along with others, following rules, and with self-control. The Level Two individual has demonstrated the desire to change and has accepted personal responsibility for change. To demonstrate Level Two behavior, you:

1. Complete four of five academic assignments a day. (Your classroom teacher and counselor determine whether work is completed.) Leaving class without permission is the same as refusing to work. It is up to the teacher and counselor to make sure the work is appropriate.

2. Attend school four of five days, have no more than four absences in any 4-week period (excused or unexcused). If you have more than four absences in one 4-week period, a team meeting will be held to determine if you can remain on level.

3. Maintain a daily average of 115 points (maximum points that can be earned a day is 175 ).

\section{How do you get from Level Two to Level Three?}

1. Complete five of five assignments at least four days a week.

2. Complete work on time four of five assignments a day, four days a week.

3. New students must attend five of five days during the first week.

4. Average at least 134 points a day for at least one week.

5. Petition to move to Level Three.

6. Attend four of five days, with no unexcused absences the week you petition.

\section{Restrictions}

1. No field trips, including swimming, bowling, and skating.

2. No team sports.

3. Supervised, room-restricted lunch periods.

4. No video games or radio/cassette player.

5. No visiting.

6. No off-grounds contracts.

7. No phone call privileges.

8. No work study.

9. No community job sites.

10. Can enter hall during scheduled bathroom breaks only with adult supervision.

\section{Privileges}

1. Earn points.

2. Cigarette breaks - limited to two a day (after breakfast, after lunch, if smoking permit has been purchased with points).

3. Can have on-grounds contracts (walking around building, shooting baskets in gym, visiting with staff with pass).

4. Can use store, but no credit will be extended, and no layaways. 


\section{TABLE 3}

PALS

\begin{tabular}{|c|c|c|}
\hline Length of stay & Requirements & Incentives \\
\hline $\begin{array}{l}\text { Levell } \\
20 \text { days } \\
\text { (or as } \\
\text { contracted } \\
\text { with teacher) }\end{array}$ & $\begin{array}{l}\text { Personal goal-setting conference. } \\
\text { Personal IEP conference. } \\
\text { Learn school rules, PALS rules, daily routine. } \\
\text { Log in journal daily } \\
\text { Keep record of assignments. } \\
\text { Participate in weekly group therapy. } \\
\text { Maintain appropriate behavior } 70 \% \text { of the time. } \\
\text { Complete } 65 \% \text { of assignments } \\
\text { Participate in required class activities. } \\
\text { Document "helping others project" on a weekly } \\
\text { basis. } \\
\text { Maintain stable attendance. } \\
\text { Progress on } 60 \% \text { of IEP goals. } \\
\text { Contained for all classes except PE. } \\
\text { Pass } 75 \% \text { of classes. }\end{array}$ & $\begin{array}{l}\text { In-school field trips. } \\
\text { One cafeteria pass per week. } \\
\text { Off-campus lunch with teacher. } \\
\text { Break time with teacher. } \\
\text { Bonus days. } \\
\text { Free time in class. } \\
\text { Food privileges in classroom. }\end{array}$ \\
\hline $\begin{array}{l}\text { Level II } \\
\qquad 30 \text { days }\end{array}$ & $\begin{array}{l}\text { Log in journal three times each week. } \\
\text { Personal IEP conference to review objectives } \\
\text { and program. } \\
\text { Participate in weekly group therapy. } \\
\text { Complete } 75 \% \text { of assignments. } \\
\text { Maintain appropriate behavior } 75 \% \text { of the time. } \\
\text { Participate in required class activities. } \\
\text { Attend regular class for } 1-3 \text { classes. } \\
\text { Maintain stable attendance. } \\
\text { Progress on } 75 \% \text { of IEP goals. } \\
\text { Pass all classes. }\end{array}$ & $\begin{array}{l}\text { In-school field trips. } \\
\text { Bonus days. } \\
2 \text { cafeteria passes per week. } \\
2 \text { off-campus lunches with teacher. } \\
\text { Free time in class. }\end{array}$ \\
\hline $\begin{array}{l}\text { Level III } \\
\quad 40 \text { days }\end{array}$ & $\begin{array}{l}\text { Log in journal weekly. } \\
\text { Participate in weekly group therapy. } \\
\text { Complete } 85 \% \text { of weekly assignments. } \\
\text { Maintain appropriate behavior } 90 \% \text { of the time. } \\
\text { Integration into four academic classes and P.E. } \\
\text { Document helping others project. } \\
\text { Maintain stable attendance. } \\
\text { Progress on } 90 \% \text { of IEP goals. } \\
\text { Pass all classes. } \\
\text { Participate in required class activities. }\end{array}$ & $\begin{array}{l}\text { Three cafeteria passes per week. } \\
\text { Up to four outside lunches with teacher. } \\
\text { Food privileges in classroom. } \\
\text { In-school field trips. } \\
\text { Outside field trips. } \\
\text { Bonus days. } \\
\text { Free time in classroom. }\end{array}$ \\
\hline $\begin{array}{l}\text { Level IV } \\
50 \text { days }\end{array}$ & $\begin{array}{l}\text { Maintain stable attendance. } \\
\text { Complete } 90 \% \text { of all assignments. } \\
\text { Maintain appropriate behavior } 90 \% \text { of the time. } \\
\text { Integrated for all classes. } \\
\text { Pass all classes. } \\
\text { Progress on } 100 \% \text { of IEP goals to criteria. } \\
\text { Contact with special teacher daily. }\end{array}$ & $\begin{array}{l}\text { Free time in class. } \\
\text { Cafeteria passes. } \\
\text { Off-campus lunch and breakfast with teacher. } \\
\text { Food privileges in classroom. } \\
\text { In-school field trips. } \\
\text { Outside field trips. } \\
\text { Bonus days. }\end{array}$ \\
\hline
\end{tabular}




\section{TABLE 3 (continued)}

\begin{tabular}{ll} 
Level V & No progress notes from regular teachers. \\
(Exit) & Pass all classes. \\
25 days & Integrated into all classes. \\
& Maintain appropriate behavior $100 \%$ of the time. \\
& Maintain stable attendance. \\
\hline
\end{tabular}

\author{
Student is monitored only. \\ Beginning at day 15 , special teacher begins \\ arrangement for permanent regular \\ educational placement.
}

Source: Personal Adjustment Level System, Hinsdale, Illinois, South High School. Adapted by permission.

PALS example. Students may contract or negotiate with the teacher to determine whether they may change levels. The classroom group may collaborate on the decision that a student change levels. A student may self-select a level and negotiate maintaining that level with the teacher.

In the GCCSEC system, a minimum length of stay is designated. In the CCBD system, though specific criteria are provided for movement, students must complete a written petition to change levels. It should be determined by whom and how frequently student status will be reviewed. Student involvement in the evaluation process facilitates self-control and decision making.

9. Determine the communication system among special and regular eduction staff, parents, student, and others. An effective levels system necessitates frequent communication. An informational meeting for parents and others new to the program may be appropriate. The CCBD provides each student with a handbook describing the system. Communication may be facilitated by group meetings, individual conferences, notes, checklists, and forms.

10. Determine augmentive systems. While using a levels system, it may be desirable to use contingency contracts or a token economy. Students may earn bonus points for outstanding gains and positive behavior. In addition, individual rewards may be appropriate for meeting specific personal goals.

11. Develop the monitoring system. Both students and teachers may monitor student progress. It is useful to involve students in self-monitoring of as many personal goals as appropriate.

\section{Other Considerations When Designing a System}

Rather than beginning each student at an entry level, an "assessment level" may be developed. In this case, the student initially is assigned to the assessment level for a specific period of time. The student is assessed in comparison to the expectations of each level and then placed on the appropriate level. Rather than progressing through levels with expectations that may be inappropriately low, assessment facilitates placement at a level that encourages maximum development.

An additional consideration is the use of a Behavior Expectations Checklist for each level, such as the one given in Table 4. This checklist is reviewed by the teacher and

TABLE 4

\section{Behavior Expectations Checklist Level 2-30 Days}

\section{Requirements:}

1. Daily journal entry.

2. Personal conference with teacher to review IEP goals and to discuss progress.

3. Participation in weekly group therapy sessions.

4. Completion of $75 \%$ of weekly assignments.

5. Appropriate behavior $75 \%$ of the time.

6. Participation in required class activities.

7. Documentation of "helping others" project.

8. Integration into one to three classes.

9. Thirty consecutive days of attendance.

10. Progress on $75 \%$ of IEP goals.

11. "Passing" grades in $80 \%$ of classes.

Start date:

Completion date:

\section{Comments}

Student signature:

Teacher signature:

Source: Personal Adjustment Level System, Hinsdale, Illinois, South High School. Adapted by permission. 
the student as the student enters each level. The student keeps his or her checklist available as a reminder of current expectations. Rosenberg (1986) cautions that simply putting a system in place is not enough; a periodic, brief review of the rules maximizes the effectiveness of classroom management systems.

Teachers may wish to include attendance at counseling or therapy sessions as a requirement for remaining at level, as in the PALS system. In addition, participation in study skills seminars, social skills training, homework, and similar activities may be included in the expectations and requirements.

\section{Advantages of Levels Systems}

To increase the probability of student self-management, levels systems employ the principle of shaping or successive approximations. A strong advantage of the systems approach, then, is that the structure employs self-monitoring, self-evaluation, and self-reinforcement, all of which have been related to increased self-management (Kanfer \& Grimm, 1978). Progress through the levels is marked with increased behavioral expectations and privileges in response to student positive behavior change; the gradual increase of demands progresses toward the goal of self-management.

Levels systems provide a differentiated continuum of services with more gradation for students who have behavioral disorders (Forness, 1981) than some other management systems. In addition, levels systems are not unnecessarily directive, overly intrusive, or choice-limiting, consequently limiting countercontrol (Seay, Suppa, Schoen, \& Roberts, 1984). The advantages of the levels systems approach are similar to those of the positive peer culture approach (Carducci, 1980) - that is, removal of the teacher from an embattled "me against them" classroom climate. In addition, like the positive peer culture, the levels system approach encourages teachers to respect the strengths and abilities of students, facilitates implementation of various individual and group interventions, and addresses problem ownership difficulties that occur among students and teachers.

\section{Disadvantages of Levels Systems}

A well designed, individualized levels system addresses students' personal goals, but a district-wide mandated system may limit teacher creativity and student individualization. A related difficulty with a levels system is that students at times may need a therapeutic milieu beyond the time provided within the individual levels. To meet student needs, teachers then are required to sabotage the system (or students sabotage the system).

An additional disadvantage of levels systems is that they may emphasize restrictions and become response cost procedures rather than positive reinforcement systems. Rather than emphasizing the earning of points through appropriate interactions, a system may fall into the trap of removing points for failing to perform appropriately.

\section{SUMMARY}

A well developed, clearly written levels system reduces the probability that a teacher will act arbitrarily and impulsively. A sincere effort must be made to instruct students in the operation of the system-how to attain its and their goals. Through the use of levels systems, students may increase self-management skills and participate in a therapeutic relationship with the teacher.

\section{REFERENCES}

Bauer, A.M., Shea, T.M., \& Keppler, R. (1986). Levels systems: A framework for the individualization of behavior management. $B e$ havioral Disorders, 11, 28-35.

Braaten, S. (1979). The Madison School program: Programming for secondary level severely emotionally disturbed youth. Behavioral Disorders, 4, 153-162.

Brophy, J. (1982). How teachers influence what is taught and learned in classrooms. Elementary School Journal, 83, 1-13.

Carducci, D.J. (1980). Positive peer culture and assertiveness training. Behavioral Disorders, 5, 156-162.

Coghlan, A.J., Gold. S.R., Dohrenwend, E.F., \& Zimmerman, R.S. (1973). A psychobehavioral residential drug abuse program: A new adventure in adolescent psychiatry. International Journal of Addiction, $8,767-777$.

Doyle, W., \& Carter, K. (1984). Academic tasks in classrooms. Curriculum Inquiry, 14, 129-149.

Fantuzzo, J.W., Polite, K., Cook, D.M., \& Quinn, G. (1988). An evaluation of the effectiveness of teacher vs. student-management classroom interventions. Psychology in the Schools, 25(4), 54-163.

Forness, S. (1981). Concepts of learning and behavior disorders: Implications for research and practice. Exceptional Children, 48, 56-64.

Gable, R.A., \& Strain, P.S. (1981). Individualizing a token reinforcement system for the treatment of children's behavioral disorders. Behavioral Disorders, 7, 39-45.

Gersten, L. (1984). University of Northern Colorado severe ED demonstration project. In H.L. Swanson \& H.R. Reinert (Eds.), Teaching strategies for children in conflict (pp. 342-345). St. Louis: C.V. Mosby.

Hood, L., McDermott, R., \& Cole, M. (1980). "Let's try to make it a good day"-Some not so simple ways. Discourse Processes, 3, 155168.

Kanfer, F.H., \& Grimm, L.G. (1978). Freedom of choice and behavioral change. Journal of Consulting \& Clinical Psychology, 46, 873-878.

LaNunziata, L.J., Hunt, K.P., \& Cooper, J.O. (1984). Suggestions for phasing out token economy systems in primary and intermediate grades. Techniques, 1, 151-156.

Marshall, H.H. (1987). Building a learning orientation. Theory into Practice, $26,8-14$. 
Mastropieri, M.A., Jenne, T., \& Scruggs, T.E. (1988). A level system for managing problem behaviors in a high school resource program. Behavioral Disorders, 13, 202-208.

Mitchell, J.D., \& Cockrum, D.L. (1980). Positive peer culture and a levels system: A comparison in an adolescent treatment facility. Criminal Justice Behavior, 7, 399-406.

Paris, S.G., \& Oka, E.R. (1986). Self-regulated learning among exceptional children. Exceptional Children, 53, 103-108.

Puro, P., \& Bloome, D. (1987). Understanding classroom communication. Theory into Practice, 26, 26-31.

Reid, I. (1979). Developing a behavioral regime in a secure youth treatment centre. Bulletin of the British Psychological Society, 32, 207.

Rosenberg, M.S. (1986). Maximizing the effectiveness of structured classroom management programs: Implementing rule-review procedures with disruptive and distractible students. Behavioral Disorders, 11, 239-248.

Rosenstock, H.A., \& Levy, M.A. (1978). On the clinical superiority of the level system. Journal of the National Association of Private Psychiatric Hospitals, 9, 32-36.

Scobie, R. (1983). Situational teaching: Fostering self-direction in the classroom. Curriculum Inquiry, 13, 131-150.

Seay, M.B., Suppa, R.J., Schoen, S.F., \& Roberts, S.R. (1984). Countercontrol: An issue in intervention. Remedial \& Special Education, $5,38-42$.

Shea, T.M., \& Bauer, A.M. (1987). Teaching children and youth with behavior disorders. Englewood Cliffs, NJ: Prentice-Hall.

Walker, J.M., \& Shea, T.M. (1988). Behavior Management (4th ed.). Columbus, $\mathrm{OH}$ : Merrill.

\section{Adapted Physical Education in the Mainstream}

\section{Second Edition}

\author{
Bryant J. Cratty \\ University of California, Los Angeles
}

Solve the problems of mainstreaming with this lively revision of the most comprehensive text available on adapted physical education. Totally rewritten, the text features new chapters on hyperactivity, fitness, infant stimulation, and awkwardness. Specific strategies and interventions are suggested for all the handicapping and health problems found among children birth to adult who require assistance from P.E. teachers, therapists, and related personnel.

Many photos and graphics illustrate the step-by-step procedures for making physical exercise and movement an enjoyable experience for all students. You'll refer to this valuable resource time and time again.

\section{MSPECLATMDATURTS}

Covers all handicapping and health conditions encountered in P.E. classes

Gives specific suggestions for integrating activities for handicapped and nonhandicapped students

Devotes a full chapter to the recently recognized problems of awkward children

Includes new material on attention defects, hyperactivity, and autism

\section{CONHDNIS:}

I The New Challenges of Physical Education in the Mainstream

Introduction and Overview/Laws, Trends, and Individual Programs/Evaluation: Teaching Roles and Strategies/Theories and Models About Movement Activities

II Sensory Impairments

Visual Impairments/Hearing Impairments

III Behavioral and Learning Disorders

Learning Disabilities/Emotional/Behavioral Disturbances/Mental Retardation/Speech and Language Impairments

IV Central Nervous System and Neuromotor Problems Awkwardness/Brain Injuries and Cerebral Palsy/Degenerative Diseases of the Nervous System/Epilepsy and Convulsive Disorders/Muscular Dystrophy and Other Muscular Disorders

V Fitness and Structural Problems

Obesity and Fitness/Body Build and Posture/Orthopedic Impairments/Arthritis

VI Cardiovascular, Pulmonary, and Metabolic Disorders Heart Disease/Hemophilia and Sickle Cell Anemia/Asthma and Other Respiratory Conditions/Juvenile Diabetes

\section{Interventions}

Infant Stimulation/Self-Control and Attention/Rhythm, Dance, and Music/Locomotion and Variations/Balls and Other Missiles/ Body Awareness and Tumbling/Aquatics/Swimming/Games That Teach Things

8826/hardbound/ISBN 0-89108-130-5

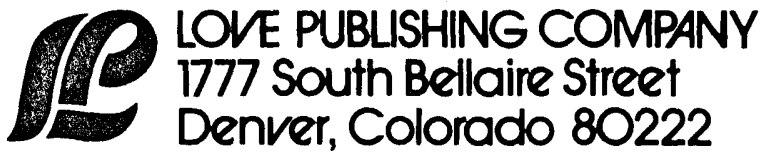

